\title{
Formulation of Trichoderma Based Biopesticide for Controlling Damping off Pathogen of Eggplant Seedling
}

\author{
Md. Jannatul Adan', Md. Abdullahil Baque ${ }^{2, *}$, Md. Mahfuzar Rahman², Md. Rafiqul Islam", \\ Afsana Jahan ${ }^{1}$ \\ ${ }^{1}$ Department of Plant pathology, Sher-e-Bangla Agricultural University, Bangladesh \\ ${ }^{2}$ Department of Agronomy, Sher-e-Bangla Agricultural University, Bangladesh
}

Copyright (C) 2015 Horizon Research Publishing All rights reserved.

\begin{abstract}
The effect of eight Trichoderma based substrates viz. rice bran, wheat bran, lentil bran, gram bran, black gram bran, mustard oil cake, grass pea bran and saw dust in mixing with peat soil and water were used in the formulation, these were evaluated for sporulations of Trichoderma harzianum and acting against Sclerotium rolfsii for the management of damping off of eggplant seedlings with control. The effect of the treatments varied significantly in terms of production of Trichoderma spore and reducing damping off and tip over increasing germination percentage, plant height, seedling vigor and fresh weight of eggplant seedlings in comparison to control. Among the treatments soil application with $\mathrm{T}_{5}$ (Trichoderma + Black gram bran + Peat soil + Water $), \mathrm{T}_{7}$ (Trichoderma + Grass Pea bran + Peat soil + Water) and $\mathrm{T}_{4}$ (Trichoderma + Gram bran + Peat soil + Water) showed the promising effect in controlling pre-emergence damping off, post-emergence damping off, tip over and increasing germination percentage, plant height, vigor index and fresh weight of seedlings. The highest germination percentage $(78.00 \%)$ was observed in treatment $\mathrm{T}_{5}$ at 16 days after sowing (DAS). The lowest percentage $(6.33 \%)$ post- emergence damping off was observed in $T_{5}$ in eggplant seedling at 16 DAS. The lowest pre- emergence damping off and tip over were observed in $\mathrm{T}_{5}$ in eggplant $(2.33 \%$ and $1.33 \%)$.
\end{abstract}

Keywords Trichoderma, Biopesticide, Damping off Pathogen, Eggplant Seedling

\section{Introduction}

The eggplant or brinjal (Solanum melongena L.) belongs the family Solanaceae (also known as the Aubergine) and genus Solanum. It is widely grown all over the world including tropical, subtropical and temperate region. Being a subtropical country it is widely grown in Bangladesh both in Rabi and kharif seasons [1]. Brinjal is the second most important vegetable crop next to potato in Bangladesh in respect of acreage and production [2]. The total area of brinjal cultivation was 78000 acres where 44000 acres was grown in Kharif season (summer) and 34000 acres in Rabi season (winter) with a total annual production of 246000 tons [2], which is very low in comparison to that of other countries like India, China, Egypt etc. Such a potential crop is known to suffer from twelve diseases. Among them damping off and foot rot caused by Sclerotium rolfsii has been treated as one of the major constrains of eggplant cultivation [3].Damping off is serious disease of vegetables grown in nursery bed. The most common fungi reported to be responsible for damping off are Pythium sp., Fusarium oxysporum, Sclerotium rolfsii, Phytophthora $s p$. and Rhizoctonia solani etc. [4,5].The fungiFusarium oxysporum, Sclerotium rolfsii and Rhizoctonia solani are soil inhibiting pathogen with wide host range and therefore, very difficult to control them.[6,7,8,9].There are several methods for controlling damping off diseaseof seedling.Trichoderma spp.has played a considerable role as biocontrol agent [10] and is recognized as an effective biocontrol agent against soil-borne plant pathogenic fungi such as Fusarium, Sclerotium, Rhizoctonia etc. [11]. Trichoderma significantly destroys the sclerotia of $S$. rolfsii [12] and it is antagonistic to S. rolfsii, overlaps the pathogen and suppresses their growth [13]. Trichoderma produces chemicals called trichodermin which is responsible for its antagonistic properties [14].Thus $T$. harzianum may be used as an ecofriendly option to save many beneficial micro-organisms in the nature. This biocontrol agent would be potential to protect seedlings against diverse soil borne pathogenic fungi. It is also reported that Trichoderma has promising contribution in plant growth $[15,16]$. The economic mass production of antagonists could be achieved by using readily available crude agricultural product. Various substrates like grain bran [17] celatom and molasses [18], wheat straw [19], wheat bran [20], cereal meal and sand [21],barley grain [22] wheat bran and saw dust [23] sand and corn meal [23] and combination of different substrates have been used to produce inocula of Trichoderma spp [24]. Trichoderma harzianum CP bio-pesticide was prepared in peat soil based 
formulation combined with different carriers viz soyabean bran, maize bran, mustard oil cake, seame bran, rice bran, tea waste, wheat bran, black gram bran and sawdust bran [25]. Considering the above facts the objectives of the study was (1)To isolate Trichoderma harzianum from rhizosphere soil, (2) To formulate Trichoderma based biopesticide using different grain brans and peat soil based substrates, (3) To find out the efficacy of biopesticide against damping off of eggplant seedlings and(4) To determine the sustainability of Trichoderma in different formulations.

\section{Materials and Methods}

The experiments were conducted at the central laboratory as well as in the nursery house Department of Plant Pathology, Sher-e-Bangla Agricultural University, Dhaka, 1207. Plastic tray or soil pots were used as unit plot. The experiments were carried out during the period from December 2013 to September 2014. Trichoderma sp. was isolated from rhizosphere soil from four different Districts (Gazipur, Dhaka, comilla and Rangpur) in Bangladesh by soil dilution technique. Peat soil was collected from Tungipara, Gopalgonj, Bangladesh. Substrates were collected from local shops of Kawran Bazar, Dhaka. Substrates were kept in $4^{0} \mathrm{C}$ until use. Eggplant (BARI Brinjal-1) seeds were collected from Bangladesh Agricultural Development Corporation (BADC), Gabtoli, Dhaka. All together a peat soil based substrates (substrate : peat soil : water $=1: 1: 2$ ) along with a control were explored in the experiment $\mathrm{T}_{1}$ (Trichoderma + Rice bran + Peat soil + Water), $\mathrm{T}_{2}$ (Trichoderma + Wheat bran + Peat soil + Water), $\mathrm{T}_{3}$ (Trichoderma + Lentil bran + Peat soil + Water), $\mathrm{T}_{4}$ (Trichoderma + Gram bran + Peat soil + Water), $\mathrm{T}_{5}$ $($ Trichoderma + Black gram bran + Peat soil + Water $)$, $\mathrm{T}_{6}($ Trichoderma + Mustard oil cake + Peat soil + Water $), \mathrm{T}_{7}$ ( Trichoderma + Grass Pea bran + Peat soil + Water), $\mathrm{T}_{8}$ ( Trichoderma + Saw Dust + Peat soil + Water). The requisite amount of materials for each substrates were thoroughly mixed in a $1000 \mathrm{ml}$ Erlenmeyer flask and autoclaved at $121^{\circ} \mathrm{C}$ for 15 minutes for sterilization. The sterilized substrates allowed to cool down and then inoculated with $5 \mathrm{~mm}$ dia mycelia disc of 7 days old Trichoderma culture. Seven discs for each flask were used for inoculation. Inoculated flasks were then incubated at room temperature $(25 \pm 2)^{0} \mathrm{C}$. After incubation for 25 days, the contents were taken out from the flasks, air dried in laminar airflow cabinet and grinded in a blender. The grinded materials were kept in polythene bag with labeling and treated as formulated Trichoderma. The spores of Trichoderma per gram of formulated products were measured by Haemocytometer. Number of spores/conidia per $\mathrm{ml}$ spread is counted with the help of Haemocytometer following the procedure of Ashrafuzzaman [26].

The pathogen was obtained from naturally infected tomato plant grown in the experimental field of the Department of Plant Pathology, SAU, Dhaka. The typical collar rot symptoms of tomato plant showed a rot with dry black to brown black lesions around the stem at collar region. The plant was still alive with pale green, and reduced sized leaves. Numbers of round brown to black sclerotia were found. The infected tissue of the collar region of the plant was collected and repeatedly washed in fresh water and surface was sterilized with $10 \%$ Clorox for 1 minute followed by three times washing in distilled water. Then the pieces of infected tissue were placed on PDA acidified with one drop of 5\% lactic acid and inoculated at $22 \pm 2{ }^{\circ} \mathrm{C}$ for 7 days. After incubation, white mycelia and sclerotia were formed. The pathogen was purified and multiplied subsequently through hyphal tip culture on PDA, for preparation of inocula. Barley culture method was followed to culture and multiply Sclerotium rolfsii [27]. Inocula of Sclerotium rolfsii were prepared in barley culture. Barley grains collected from market were thoroughly washed in water and kept soaked in fresh water for $24 \mathrm{hrs}$. After decantation, barley grains were taken in $500 \mathrm{ml}$ Erlenmeyer flask at the rate of $200 \mathrm{~g}$ in each. The flasks were plugged with cotton followed by wrapping the mouth with brown paper. The flasks containing moist barley grains were sterilized in autoclave at $121^{\circ} \mathrm{C}$ under $15 \mathrm{lbs}$ pressure for 15 minutes. The sterilized barley grains in the flask were cooled and inoculated aseptically with mycelial blocks $(5 \mathrm{~mm})$ of pure culture of Sclerotium rolfsii on PDA and inoculated at room temperature for 7-8 days. The flasks were shaken periodically with hand for proper distribution of fungal mycelium throughout the entire mass of the inoculated barley grains. The mycelial growth of the fungus covered entire barley mass in the flask when small round white sclerotia started to form. It was taken out of the flask after fifteen days. The entire mass was spread on brown paper and air dried at room temperature. The colonized dried barley grains were used as inocula for inoculation of plants

Soil and cow dung were mixed in (2:1) ratio and kept for 15 days and then the soil sterilized with $5 \mathrm{ml}$ formalin (40\%) diluted with $20 \mathrm{ml}$ water for $4 \mathrm{~kg}$ soil [28] and the prepared soil was heaped in square block. Soil heap was covered by polyethylene sheet for $48 \mathrm{hr}$. After 4 days of treatment pots were filled up with the sterilized soil.

Formulated Trichoderma were mixed with the soil (except control)@ of 20g/kg soil. The treated soil was incubated for 7 days maintaining proper soil moisture. After that, soil was inoculated with barley grain colonized by Sclerotium rolfsii (a) $20 \mathrm{~g} / \mathrm{kg}$ of soil. Inoculated soil was incubated for 7 days maintaining proper soil moisture. One hundred seeds of eggplant were sown in each soil pot after 7 days of application of formulated Trichoderma and Sclerotium rolfsii.

The data were recorded on the following parameters- $\%$ of seed germination, $\%$ pre-emergence damping off, $\%$ post-emergence damping, \% tip over, seedling height, vigor index and fresh weight of seedling. The collected data were compiled and analyzed statistically using the analysis of variance (ANOVA) technique with the help of a computer package program MSTAT-C and the mean differences were 
adjusted by Duncan's Multiple Range Test (DMRT) [29].

\section{Results}

\section{Number of spore $/ \mathrm{mm}^{2}\left(\times 10^{4}\right)$ in different Trichoderma isolates:}

Number of spores in different Trichoderma harzianum isolates was presented in (Table 1). The highest number of spore $/ \mathrm{mm}^{2}$ was observed in isolate $\mathrm{T}_{1}$ (TJG- Trichoderma harzianum, Joydevpur, Gazipur) $\left(6.42 \times 10^{4}\right)$ followed by isolate $\mathrm{T}_{2}$ (TSD - Trichoderma harzianum, Sher-e-Bangla Nagar, Dhaka) $\left(5.70 \times 10^{4}\right)$. The lowest number of spore $/ \mathrm{mm}^{2}$ was observed in isolate $\mathrm{T}_{4}$ (TTR - Trichoderma harzianum, Taragonj, Rangpur) $\left(5.13 \times 10^{4}\right)$ preceded by isolate $\mathrm{T}_{3}$ (TCC - Trichoderma harzianum, Chandina, Comilla) $\left(5.30 \times 10^{4}\right)$. Based on the higher spore production isolate $\mathrm{T}_{1}$ (TJG Trichoderma harzianum, Jodevpur, Gazipur) was considered to make the subsequent formulation.

Table 1. Number of spore $/ \mathrm{mm}^{2}\left(\times 10^{4}\right)$ in different Trichoderma isolates

\begin{tabular}{|c|c|}
\hline Trichoderma Isolate & No. of spore $/ \mathrm{mm}^{2}\left(\times 10^{4}\right)$ \\
\hline $\mathrm{T}_{1}-\mathrm{TJG}$ & $6.42 \mathrm{a}$ \\
\hline $\mathrm{T}_{2}-\mathrm{TSD}$ & $5.70 \mathrm{~b}$ \\
\hline $\mathrm{T}_{3}-\mathrm{TCC}$ & $5.30 \mathrm{c}$ \\
\hline $\mathrm{T}_{4}-\mathrm{TTR}$ & $5.13 \mathrm{c}$ \\
\hline $\mathrm{LSD}_{(0.05)}$ & 0.31 \\
\hline $\mathrm{CV}(\%)$ & 2.97 \\
\hline
\end{tabular}

$\mathrm{T}_{1}=$ (TJG - Trichoderma harzianum, Joydevpur, Gazipur), $\mathrm{T}_{2}=(\mathrm{TSD}-$ Trichoderma harzianum, Sher-e-Bangla Nagar, Dhaka), $\mathrm{T}_{3}=$ (TCC Trichoderma harzianum, Chandina , Comilla), $\mathrm{T}_{4}=(\mathrm{TTR}-$ Trichoderma harzianum, Taragonj, Rangpur).

\section{Effect of different substrates on mass multiplication of} Trichoderma harzianum

Table 2. Effect of different substrates on mass multiplication of Trichoderma harzianum

\begin{tabular}{|c|c|}
\hline Treatment & No. of spore $/ \mathrm{gm}\left(\times 10^{7}\right)$ \\
\hline $\mathrm{T}_{1}$ & $24.27 \mathrm{a}$ \\
\hline $\mathrm{T}_{2}$ & $22.23 \mathrm{~b}$ \\
\hline $\mathrm{T}_{3}$ & $21.23 \mathrm{c}$ \\
\hline $\mathrm{T}_{4}$ & $20.23 \mathrm{~d}$ \\
\hline $\mathrm{T}_{5}$ & $19.50 \mathrm{e}$ \\
\hline $\mathrm{T}_{6}$ & $18.23 \mathrm{f}$ \\
\hline $\mathrm{T}_{7}$ & $16.23 \mathrm{~g}$ \\
\hline $\mathrm{T}_{8}$ & $10.23 \mathrm{~h}$ \\
\hline $\mathrm{LSD}_{(0.05)}$ & 0.49 \\
\hline $\mathrm{CV}_{(\%)}$ & 1.48 \\
\hline
\end{tabular}

$\mathrm{T}_{1}=$ Trichoderma + Black gram bran + Peat soil + Water, $\mathrm{T}_{2}=$ Trichoderma + Grass pea bran + Peat soil + Water, $\mathrm{T}_{3}=$ Trichoderma + Gram bran + Peat soil + Water, $\mathrm{T}_{4}=$ Trichoderma + Wheat bran + Peat soil + Water, $\mathrm{T}_{5}=$ Trichoderma + Rice bran + Peat soil + Water, $\mathrm{T}_{6}=$ Trichoderma + Lentil bran + Peat soil + Water, $\mathrm{T}_{7}=$ Trichoderma + Mustard oil cake + Peat soil + Water, $\mathrm{T}_{8}=$ Trichoderma + Saw dust + Peat soil + Water.
Inoculum potentials in respect of number spore of Trichoderma harzianum in different treatments was presented in (Table 2). All the treatments were differed significantly in terms of number of spores of Trichoderma harzianum. The highest number of spore/gm $\left(24.27 \times 10^{7}\right)$ was observed in $\mathrm{T}_{1}$ where black gram bran and peat soil were mixed with water at 1:1:2 ratio followed by $\mathrm{T}_{2}\left(22.23 \times 10^{7}\right)$ where grass pea bran was mixed with peat soil and water at 1:1:2 ratio. The third highest number of spore/gm $\left(21.23 \times 10^{7}\right)$ was observed in $\mathrm{T}_{3}$ (Gram bran + Peat soil + Water, ratio $-1: 1: 2$ ) followed by treatment $\mathrm{T}_{4}$ (Wheat bran + Peat soil + Water, ratio $-1: 1: 2)\left(20.23 \times 10^{7}\right)$. The lowest number of spore/gm was observed in $\mathrm{T}_{8}$ (Saw Dust + Peat soil + Water, ratio $-1: 1: 2) \quad\left(10.23 \times 10^{7}\right)$ preceded by treatment $T_{7}$ $\left(16.23 \times 10^{7}\right)$. In case of $\mathrm{T}_{5}$ and $\mathrm{T}_{6}$ number of spore/gm were $19.50 \times 10^{7}$ and $18.23 \times 10^{7}$.

\section{Effect of different treatments on germination of eggplant seedlings at 10 days after sowing}

The effect of treatments on germination of eggplant seedlings at different days after sowing (DAS) was presented in (Table 3). The effect of different treatments on germination of eggplant seedlings were differed significantly in comparison to control. At 10 DAS, the highest germination $(76.00 \%)$ was observed in $\mathrm{T}_{5}$ (Trichoderma + Black gram + Peat soil + Water) and the lowest germination $(44.00 \%)$ was observed in $\mathrm{T}_{9}$ (Control). The second highest germination $(71.67 \%)$ was observed in $\mathrm{T}_{7}$ (Trichoderma + Grass pea bran + Peat soil + Water). The effect of treatment $\mathrm{T}_{2}$ (Trichoderma + Wheat bran + Peat soil + Water) on germination at 10 DAS was statistically similar with the effect of treatment $\mathrm{T}_{1}$ (Trichoderma + Rice bran + Peat soil + Water). The effect of treatment $\mathrm{T}_{6}$ (Trichoderma + Mustered oil cake + Peat soil + Water) on germination at 10 DAS was statistically similar with the effect of treatment $T_{8}$ (Trichoderma + Saw dust + Peat soil + Water $)$

\section{Effect of different treatments on the germination of eggplant seedlings at 13 days after sowing}

A remarkable effect was observed among the treatments on the germination at 13 DAS of eggplant seedling (Table 3). The effect of different treatments on germination of eggplant seedlings were differed significantly in comparison to control. The highest germination $(77.00 \%)$ was observed in $\mathrm{T}_{5}$ (Trichoderma + Black gram + Peat soil + Water) and the lowest germination $(45.33 \%)$ was observed in $\mathrm{T}_{9}$ (Control). The second highest germination $(72.67 \%)$ was observed in $\mathrm{T}_{7}$ (Trichoderma + Grass pea bran + Peat soil + Water $)$ which was statistically similar with treatment $\mathrm{T}_{4}$ (Trichoderma + Gram bran + Peat soil + Water) $(69.00 \%)$. The effect of treatment $\mathrm{T}_{2}$ (Trichoderma + Wheat bran + Peat soil + Water $)$ on germination at 13 DAS was statistically similar with the effect of treatment $\mathrm{T}_{1}$ (Trichoderma + Rice bran + Peat soil + Water). The effect of treatment $T_{6}$ on germination at 10 DAS was statistically similar with the effect of treatment $\mathrm{T}_{8}$. 


\section{Effect of different treatments on the germination of eggplant seedlings at 16 days after sowing}

The effect of different treatments on germination of eggplant seedlings at 16 DAS varied significantly in comparison to control (Table 3). At 16 DAS, the highest germination $(78.00 \%)$ was observed in $\mathrm{T}_{5}$ (Trichoderma + Black gram + Peat soil + Water) and the lowest germination $(46.33 \%)$ was observed in $\mathrm{T}_{9}$ (Control). The second highest germination $(72.67 \%)$ at the same days after sowing was observed in $\mathrm{T}_{7}$ (Trichoderma + Grass pea bran + Peat soil + Water) which was statistically similar with treatment $\mathrm{T}_{4}$ $(70.00 \%)$. The effect of treatment $\mathrm{T}_{2}$ (Trichoderma + Wheat bran + Peat soil + Water) on germination at 13 DAS was statistically similar with the effect of treatment $T_{1}$ (Trichoderma + Rice bran + Peat soil + Water). The effect of treatment $\mathrm{T}_{3}$ on germination at 13 DAS was statistically similar with the effect of treatment $\mathrm{T}_{6}$. According to the performance of the treatments the highest increase of seed germination $(68.36 \%)$ was counted in $\mathrm{T}_{5}$ (Trichoderma + Black gram + Peat soil + Water) followed by $\mathrm{T}_{7}(56.85 \%)$ (Trichoderma + Grass pea bran + Peat soil + Water $), \mathrm{T}_{4}$ $(51.10 \%)$ (Trichoderma + Gram bran + Peat soil + Water $)$ and $\mathrm{T}_{2}(40.29 \%)$ (Trichoderma + Wheat bran + Peat soil + Water) respectively.

Table 3. Effect of different treatments on the germination of eggplant seedlings at different days after sowing (DAS)

\begin{tabular}{|c|c|c|c|c|}
\hline \multirow{2}{*}{ Treatment } & \multicolumn{3}{|c|}{$\%$ Germination } & $\begin{array}{c}\text { \% germination } \\
\text { increased over } \\
\text { control }\end{array}$ \\
\cline { 2 - 5 } & $10 \mathrm{DAS}$ & $13 \mathrm{DAS}$ & $16 \mathrm{DAS}$ & $16 \mathrm{DAS}$ \\
\hline $\mathrm{T}_{1}$ & $61.00 \mathrm{~d}$ & $62.00 \mathrm{~cd}$ & $63.00 \mathrm{~cd}$ & 35.98 \\
\hline $\mathrm{T}_{2}$ & $63.00 \mathrm{~d}$ & $64.00 \mathrm{c}$ & $65.00 \mathrm{c}$ & 40.29 \\
\hline $\mathrm{T}_{3}$ & $57.00 \mathrm{e}$ & $58.00 \mathrm{de}$ & $60.00 \mathrm{de}$ & 29.50 \\
\hline $\mathrm{T}_{4}$ & $68.00 \mathrm{c}$ & $69.00 \mathrm{~b}$ & $70.00 \mathrm{~b}$ & 51.10 \\
\hline $\mathrm{T}_{5}$ & $76.00 \mathrm{a}$ & $77.00 \mathrm{a}$ & $78.00 \mathrm{a}$ & 68.36 \\
\hline $\mathrm{T}_{6}$ & $53.00 \mathrm{f}$ & $55.00 \mathrm{ef}$ & $57.33 \mathrm{e}$ & 23.74 \\
\hline $\mathrm{T}_{7}$ & $71.67 \mathrm{~b}$ & $72.67 \mathrm{~b}$ & $72.67 \mathrm{~b}$ & 56.85 \\
\hline $\mathrm{T}_{8}$ & $50.00 \mathrm{f}$ & $51.00 \mathrm{f}$ & $52.00 \mathrm{f}$ & 12.24 \\
\hline $\mathrm{T}_{9}$ & $44.00 \mathrm{~g}$ & $45.33 \mathrm{~g}$ & $46.33 \mathrm{~g}$ & - \\
\hline $\mathrm{LSD}_{(0.05)}$ & 3.09 & 4.15 & 4.35 & - \\
\hline $\mathrm{CV}_{(\%)}$ & 2.99 & 3.93 & 4.05 & - \\
\hline
\end{tabular}

$\mathrm{T}_{1}=$ Trichoderma + Rice bran + Peat soil + Water, $\mathrm{T}_{2}=$ Trichoderma + Wheat bran + Peat soil + Water, $\mathrm{T}_{3}=$ Trichoderma + Lentil bran + Peat soil + Water, $\mathrm{T}_{4}=$ Trichoderma + Gram bran + Peat soil + Water, $\mathrm{T}_{5}=$ Trichoderma + Black gram bran + Peat soil + Water, $\mathrm{T}_{6}=$ Trichoderma + Mustard oil cake + Peat soil + Water, $\mathrm{T}_{7}=$ Trichoderma + Grass pea bran + Peat soil + Water, $\mathrm{T}_{8}=$ Trichoderma + Saw dust + Peat soil + Water, $\mathrm{T}_{9}=$ Control.

Effect of different treatments on the post-emergence damping off of eggplant seedlings at 10 days after sowing

The effect of different treatments varied significantly in respect of post-emergence damping off percentage at 10 DAS (Table 4). The highest percent post-emergence damping off was recorded in control (25.00\%) and the second highest post-emergence damping off at 10 DAS was observed in treatment $\mathrm{T}_{8}$ (Trichoderma + Saw dust + Peat soil + Water) which was statistically similar with $T_{3}$ (Trichoderma + Lentil bran + Peat soil + Water). The effect of treatment $\mathrm{T}_{2}$ on post-emergence damping off at $10 \mathrm{DAS}$ was statistically similar with treatment $T_{4}$. The effect of treatment $\mathrm{T}_{7}$ (Trichoderma + Grass pea bran + Peat soil + Water) on post-emergence damping off at 10 DAS was $7.00 \%$. The lowest percentage of post-emergence damping off $(4.00 \%)$ was recorded in treatment $\mathrm{T}_{5}$ (Trichoderma + Black gram + Peat soil + Water $)$.

Effect of different treatments on the post-emergence damping off of eggplant seedlings at 13 days after sowing

A remarkable effect was observed among the treatments in controlling post-emergence damping off disease of eggplant at 13 days after sowing (Table 4). The treatments effects were differed significantly in terms of post-emergence damping off percentage. The highest effect against post-emergence damping off $(6.00 \%)$ was observed in case of treatment $\mathrm{T}_{5}$ (Trichoderma + Black gram + Peat soil + Water). The second lowest percent post-emergence damping off $(10.00 \%)$ was observed in treatment $\mathrm{T}_{7}$ (Trichoderma + Grass Pea bran + Peat soil + Water) which was statistically similar with treatment $T_{4}$. The effect of treatment $T_{8}$ (Trichoderma + Saw dust + Peat soil + Water) on post-emergence damping off at 13 DAS was statistically similar with the treatment $\mathrm{T}_{6}$ and $\mathrm{T}_{3}$. The highest percent of post-emergence damping off $(28.00 \%)$ was observed in case of treatment $\mathrm{T}_{9}$ (Control).

Effect of different treatments on the post-emergence damping off of eggplant seedlings at 16 days after sowing

Table 4. Effect of different treatments on post-emergence damping off of eggplant seedlings at different days after sowing (DAS)

\begin{tabular}{|c|c|c|c|c|}
\hline \multirow{2}{*}{ Treatment } & \multicolumn{3}{|c|}{$\%$ Post-emergence damping off } & \multirow{2}{*}{$\begin{array}{c}\% \\
\text { post-emergence } \\
\text { damping off } \\
\text { reduced over } \\
\text { control }\end{array}$} \\
\hline & 10 DAS & 13 DAS & 16 DAS & \\
\hline $\mathrm{T}_{1}$ & $15.00 \mathrm{~d}$ & $17.00 \mathrm{~cd}$ & $19.33 \mathrm{c}$ & 35.57 \\
\hline $\mathrm{T}_{2}$ & $12.33 \mathrm{e}$ & $15.00 \mathrm{~d}$ & $17.00 \mathrm{~d}$ & 43.33 \\
\hline $\mathrm{T}_{3}$ & $17.67 \mathrm{bc}$ & $19.00 \mathrm{bc}$ & $19.67 \mathrm{c}$ & 34.43 \\
\hline $\mathrm{T}_{4}$ & $11.00 \mathrm{e}$ & $11.33 \mathrm{e}$ & $12.67 \mathrm{e}$ & 57.77 \\
\hline $\mathrm{T}_{5}$ & $4.000 \mathrm{~g}$ & $6.00 \mathrm{f}$ & $6.33 \mathrm{~g}$ & 78.90 \\
\hline $\mathrm{T}_{6}$ & $17.00 \mathrm{c}$ & $20.00 \mathrm{~b}$ & $20.00 \mathrm{c}$ & 33.33 \\
\hline $\mathrm{T}_{7}$ & $7.00 \mathrm{f}$ & $10.00 \mathrm{e}$ & $10.33 \mathrm{f}$ & 65.57 \\
\hline $\mathrm{T}_{8}$ & $19.33 \mathrm{~b}$ & $21.00 \mathrm{~b}$ & $23.67 \mathrm{~b}$ & 21.10 \\
\hline $\mathrm{T}_{9}$ & $25.00 \mathrm{a}$ & $28.00 \mathrm{a}$ & $30.00 \mathrm{a}$ & - \\
\hline $\operatorname{LSD}_{(0.05)}$ & 1.89 & 2.24 & 1.71 & - \\
\hline $\mathrm{CV}(\%)$ & 7.75 & 7.97 & 5.66 & - \\
\hline
\end{tabular}

$\mathrm{T}_{1}=$ Trichoderma + Rice bran + Peat soil + Water, $\mathrm{T}_{2}=$ Trichoderma + Wheat bran + Peat soil + Water, $\mathrm{T}_{3}=$ Trichoderma + Lentil bran + Peat soil + Water, $\mathrm{T}_{4}=$ Trichoderma + Gram bran + Peat soil + Water, $\mathrm{T}_{5}=$

Trichoderma + Black gram bran + Peat soil + Water, $\mathrm{T}_{6}=$ Trichoderma + Mustard oil cake + Peat soil + Water, $\mathrm{T}_{7}=$ Trichoderma + Grass pea bran + Peat soil + Water, $\mathrm{T}_{8}=$ Trichoderma + Saw dust + Peat soil + Water, $\mathrm{T}_{9}=$ Control. 
The effect of the treatments on post-emergence damping off percentage of eggplant seedlings at 16 days after sowing (DAS) was presented in (Table 4). All the treatments were differed significantly in terms of post-emergence damping off percentage. The highest percent post-emergence damping off was counted in control $(30.00 \%)$ followed by treatment $\mathrm{T}_{8}(23.67 \%)$. The effect of treatment $\mathrm{T}_{6}$ on post-emergence damping off at 16 DAS was statistically similar with the treatment $\mathrm{T}_{3}$ and $\mathrm{T}_{1}$. The lowest percent post-emergence $(6.33 \%)$ was observed in case of treatment $\mathrm{T}_{5}$ (Trichoderma + Black gram + Peat soil + Water). According to the performance of the treatments the highest reduction of post-emergence damping off $(78.90 \%)$ was counted in $\mathrm{T}_{5}$ (Trichoderma + Black gram + Peat soil + Water) followed by $\mathrm{T}_{7}(65.57 \%)$ (Trichoderma + Grass pea bran + Peat soil + Water), $\mathrm{T}_{4}(57.77 \%)$ (Trichoderma + Gram bran + Peat soil + Water) and $\mathrm{T}_{2}(43.33 \%)$ (Trichoderma + Wheat bran + Peat soil + Water) respectively.

\section{Effect of different treatments on the pre-emergence} damping off of eggplant seedlings

The effect of the treatments on pre-emergence damping off percentage of eggplant seedlings was presented in (Table 5 ). All the treatments were differed significantly in terms of pre-emergence damping off percentage. The highest percent pre-emergence damping off was observed in control (33.67\%) followed by treatment $\mathrm{T}_{8}(28.00 \%)$. The effect of treatment $\mathrm{T}_{6}$ (Trichoderma + Mustered oil cake + Peat soil + Water) on pre-emergence damping off was statistically similar with the treatment $T_{3}$. The lowest percent of pre-emergence damping off $(2.33 \%)$ was observed in case of treatment $\mathrm{T}_{5}$ (Trichoderma + Black gram + Peat soil + Water). The second lowest percent of pre-emergence damping off $(7.33 \%)$ was recorded in treatment $T_{7}$ (Trichoderma + Grass pea bran + Peat soil + Water) which was statistically similar with treatment $\mathrm{T}_{4}$.

\section{Effect of different treatments on the tip over of eggplant seedlings}

The effect of the treatments on tip over of eggplant seedlings was presented in (Table 5). All the treatments were differed significantly in comparison to control. The highest percent tip over was observed in control $(19.00 \%)$ followed by treatment $\mathrm{T}_{8}(13.00 \%)$. The effect of treatment on tip over percentage $(9.00 \%)$ was observed in $T_{6}$ followed by $T_{3}$ $(7.00 \%)$. The lowest percent of tip over $(1.33 \%)$ was recorded in treatment $\mathrm{T}_{5}$ (Trichoderma + Black gram + Peat soil + Water). The second lowest percent of tip over (3.00\%) was observed in case of treatment $\mathrm{T}_{7}$ (Trichoderma + Grass pea bran + Peat soil + Water) preceded by treatment $\mathrm{T}_{4}$ (Trichoderma + Gram bran + Peat soil + Water) $(3.67 \%)$.

\section{Effect of different treatments on plant height, of eggplant seedlings}

The treatments effect on plant height of eggplant seedlings was presented in (Table 5). All the treatments had significant impact on plant height of eggplant seedlings. The highest plant height was observed in case of $\mathrm{T}_{5}$ (Trichoderma + Black gram + Peat soil + Water) (5.31) followed by $\mathrm{T}_{7}$ (Trichoderma + Grass Pea bran + Peat soil + Water) (3.11). The third highest plant height was observed in treatment $\mathrm{T}_{4}$ (3.77) which was statistically similar with both $T_{1}$ and $T_{2}$. The lowest plant height was observed in case of control $\mathrm{T}_{9}$ (2.22). The second lowest plant height was observed in $T_{8}$ (2.71).

\section{Effect of different treatments on seedlings vigor of eggplant}

The treatments effect on vigor index, of eggplant seedlings was presented in (Table 5). All the treatments were differed significantly in terms of vigor index of eggplant seedlings. The highest vigor index (4.14) was observed in case of $\mathrm{T}_{5}$ (Trichoderma + Black gram + Peat soil + Water) followed by $\mathrm{T}_{7}$ (6.59) (Trichoderma + Grass Pea bran + Peat soil + Water). The vigor index (2.64) observed in case of $\mathrm{T}_{4}$ (Trichoderma + Gram bran + Peat soil + Water). The effect of different treatments in vigor index was statistically similar in both $T_{2}$ and $T_{1}$. The lowest vigor index was observed in case of control $\mathrm{T}_{9}$ (1.03) preceded by $\mathrm{T}_{8}(1.41)$ and $\mathrm{T}_{6}(1.74)$.

\section{Effect of different treatments on fresh weight of eggplant seedlings}

The treatments effect on fresh weight of brinjal seedlings was recorded and presented in (Table 5). All the treatments were differed significantly in terms of fresh weight of brinjal seedlings. The highest fresh weight was observed in case of $\mathrm{T}_{5}$ (Trichoderma + Black gram + Peat soil + Water $)(3.90 \mathrm{gm})$ followed by $\mathrm{T}_{7}$ (Trichoderma + Grass pea bran + Peat soil + Water) $(2.69 \mathrm{gm})$. The third highest fresh weight was observed in case of $\mathrm{T}_{4}$ (Trichoderma + Gram bran + Peat soil + Water) $(2.14 \mathrm{gm})$ followed by $\mathrm{T}_{2}$ (Trichoderma + Wheat bran + Peat soil + Water) $(1.95 \mathrm{gm})$. The lowest fresh weight was observed in case of control $\mathrm{T}_{9}(1.00 \mathrm{gm})$ preceded by $\mathrm{T}_{8}$ (Trichoderma + Saw dust + Peat soil + Water) $(1.30 \mathrm{gm})$ which was statistically identical with $\mathrm{T}_{6}$ (Trichoderma + Mustered oil cake + Peat soil + Water) (1.37gm). 
Table 5. Effect of different treatments on pre-emergence damping off, tip over, plant height, vigor index and fresh weight of eggplant seedlings

\begin{tabular}{|c|c|c|c|c|c|}
\hline Treatment & \% Pre-emergence damping off & \% Tip over & Plant height $(\mathrm{cm})$ & Vigor index & Fresh weight (gm) \\
\hline $\mathrm{T}_{1}$ & $17.00 \mathrm{de}$ & $5.67 \mathrm{e}$ & $3.50 \mathrm{~cd}$ & $2.21 \mathrm{de}$ & $1.78 \mathrm{e}$ \\
\hline $\mathrm{T}_{2}$ & $15.00 \mathrm{e}$ & $4.67 \mathrm{f}$ & $3.60 \mathrm{~cd}$ & $2.34 \mathrm{~d}$ & $1.95 \mathrm{~d}$ \\
\hline $\mathrm{T}_{3}$ & $20.00 \mathrm{~cd}$ & $7.00 \mathrm{~d}$ & $3.33 \mathrm{de}$ & $2.00 \mathrm{e}$ & $1.53 \mathrm{f}$ \\
\hline $\mathrm{T}_{4}$ & $10.00 \mathrm{f}$ & $3.67 \mathrm{~g}$ & $3.77 \mathrm{c}$ & $2.64 \mathrm{c}$ & $2.14 \mathrm{c}$ \\
\hline $\mathrm{T}_{5}$ & $2.33 \mathrm{~g}$ & $1.33 \mathrm{i}$ & $5.31 \mathrm{a}$ & $4.14 \mathrm{a}$ & $3.90 \mathrm{a}$ \\
\hline $\mathrm{T}_{6}$ & $22.67 \mathrm{c}$ & $9.00 \mathrm{c}$ & $3.04 \mathrm{e}$ & $1.74 \mathrm{f}$ & $1.37 \mathrm{~g}$ \\
\hline $\mathrm{T}_{7}$ & $7.33 \mathrm{f}$ & $3.00 \mathrm{~h}$ & $4.28 \mathrm{~b}$ & $3.11 \mathrm{~b}$ & $2.69 \mathrm{~b}$ \\
\hline $\mathrm{T}_{8}$ & $28.00 \mathrm{~b}$ & $13.00 \mathrm{~b}$ & $2.71 \mathrm{f}$ & $1.41 \mathrm{~g}$ & $1.30 \mathrm{~g}$ \\
\hline $\mathrm{T}_{9}$ & $33.67 \mathrm{a}$ & $19.00 \mathrm{a}$ & $2.22 \mathrm{~g}$ & $1.03 \mathrm{~h}$ & $1.00 \mathrm{~h}$ \\
\hline $\mathrm{LSD}_{(0.05)}$ & 4.29 & 0.66 & 0.31 & 0.21 & 4.55 \\
\hline $\mathrm{CV}_{(\%)}$ & 14.43 & 5.22 & 5.04 & 5.36 & 0.15 \\
\hline
\end{tabular}

$\mathrm{T}_{1}=$ Trichoderm $a+$ Rice bran + Peat soil + Water, $\mathrm{T}_{2}=$ Trichoderma + Wheat bran + Peat soil + Water, $\mathrm{T}_{3}=$ Trichoderma + Lentil bran + Peat soil + Water, $\mathrm{T}_{4}=$ Trichoderma + Gram bran + Peat soil + Water, $\mathrm{T}_{5}=$ Trichoderma + Black gram bran + Peat soil + Water, $\mathrm{T}_{6}=$ Trichoderma + Mustard oil cake + Peat soil + Water, $\mathrm{T}_{7}=$ Trichoderma + Grass pea bran + Peat soil + Water, $\mathrm{T}_{8}=$ Trichoderma + Saw dust + Peat soil + Water, $\mathrm{T}_{9}=$ Control .

\section{Discussion}

The present study was carried out with nine different treatments of Trichoderma based substrates were evaluated for sporulations of Trichoderma harzianum and acting against Sclerotium rolfsii for the management of damping off of eggplant seedlings. Different isolates of Trichoderma evaluated in the experiment found to be differed in terms of number of spore production. The highest number of spore $\left(6.42 \times 10^{4} / \mathrm{mm}^{2}\right)$ was observed in isolate $\mathrm{T}_{1}$ (TJG Trichoderma $s p$. Joydevpur, Gazipur) that was used in the substrate to construct the treatment combinations. In mass multiplication of Trichoderma isolate TJG (Trichoderma $s p$. Jodevpur, Gazipur) black gram brans combined with peat soil and water $(1: 1: 2 \mathrm{w} / \mathrm{w} / \mathrm{v})$ proved to be suitable substrate for producing the highest CFU/g of Trichoderma sp. Earlier studies support the results of the present findings [30,31]. Shamsuzzaman [32] reported that the highest production conidia $\left(42.93 \times 10^{7} / \mathrm{g}\right)$ were recorded in black gram based substrates while used for mass multiplication of Trichoderma isolates. Another study showed that black gram bran gave the highest cfu both in room and freezing temperature up to 210 days after inoculation with Trichoderma harzianum and peat soil [25]. Several other workers also used different agro-products for multiplication of Trichoderma sp. but they did not include peat soil based black gram brans in their study [33,34].The peat soil based Trichodermal formulation were evaluated in the nursery house against Sclerotium rolfsii for the management of eggplant seedlings. The data recorded on percent seed germination, post-emergence damping off, pre-emergence damping off, tip over, plant height and vigor index of at different days after sowing (DAS). In case of eggplant seedlings, the results revealed that the treatment $T_{5}$ (Trichoderma + Black gram bran + Peat soil + Water) and $\mathrm{T}_{7}$ (Trichoderma + Grass Pea bran + Peat soil + Water) had remarkable effect against damping off and tip over of seedlings increasing the seed germination, seedling height, vigor index and fresh weight of seedlings irrespective of days after sowing (DAS). At 16 DAS, the highest germination $(78.00 \%)$ was observed in $\mathrm{T}_{5}$ (Trichoderma + Black gram bran + Peat soil + Water) followed by $\mathrm{T}_{7}$ (Trichoderma + Grass Pea bran + Peat soil + Water). In case of post-emergence damping off at 16 DAS, the highest reduction $(78.90 \%)$ of post-emergence damping off was observed in case of treatment $\mathrm{T}_{5}$ (Trichoderma + Black gram bran + Peat soil + Water) followed by $\mathrm{T}_{7}$ (Trichoderma + Grass Pea bran + Peat soil + Water). Same was the case in pre-emergence damping off seedlings where reduction of pre-emergence damping was observed in case of treatment $\mathrm{T}_{5}$ (Trichoderma + Black gram bran + Peat soil + Water) followed by $\mathrm{T}_{7}$ (Trichoderma + Grass Pea bran + Peat soil + Water). In case of plant height, the highest plant height (5.31 $\mathrm{cm}$ ) was observed in $\mathrm{T}_{5}$ (Trichoderma + Black gram bran + Peat soil + Water) and the second highest plant height (4.28 $\mathrm{cm}$ ) was observed in $\mathrm{T}_{7}$ (Trichoderma + Grass Pea bran + Peat soil + Water). In case of vigor index the highest vigor index (4.14) was observed in $\mathrm{T}_{5}$ (Trichoderma + Black gram bran + Peat soil + Water) and the second highest highest vigor index (3.11) was observed in $\mathrm{T}_{7}$ (Trichoderma + Grass Pea bran + Peat soil + Water). In case of fresh weight of seedlings, the highest fresh weight (3.90 gm) was observed in $\mathrm{T}_{5}$ (Trichoderma + Black gram bran + Peat soil + Water) while the second highest fresh weight $(2.69 \mathrm{gm})$ was observed in $\mathrm{T}_{7}$ (Trichoderma + Grass Pea bran + Peat soil + Water). The present findings were keep in with the findings of Meah [35] who reported that Trichoderma harzianum cp and Trichoderma harzianum $\mathrm{T}_{22}$ grown on peat soil based black gram bran was found effective in controlling nursery diseases like damping off, tip over and seedling blight of eggplant and promoted seed germination. Shamsuzzaman [30] studied for mass production of Trichoderma harzianum. Of them, rice straw chick pea bran, rice course with $3 \%$ chick pea powder, rice straw with $5 \%$ sucrose black gram bran, grass pea bran and peat based wheat bran supported best in mass production of conidia $\left(42.93 \times 10^{7} / \mathrm{g}\right.$ 
culture).Shamsuzzaman[32] further reported that seed treatment with Trichoderma harzianum grown on black gram resulted up to $16.66 \%$ higher seed germination, $266.33 \%$ fresh shoot weight, $157.14 \%$ fresh root weight and 98.55 vigor index of cucurbits over control. Shahiduzzaman [36] found that $T$. harzianum present in decomposed municipality waste was effective in increased growth response by increasing number of leaves. Ozbay[37] and Mukhopodhyay[38] demonstrated increased growth of several crop plants in the presence of biological agents. These responses may be caused by a direct effect to the plant (as bio-fertilizer) or by control of some undiagnosed plant pathogens. Increase plant height, fresh and dry weight of wheat (1.5 times), cucumber (75.2 times), and radish (1.9 times) were achieved when plant growth promoting fungi (PGPF) Trichoderma were applied in the soil. Abd-El-Khair [39] found that the average of bean plant height with Trichoderma application were in the range of 46.0-49.8 cm compared to $37.3 \mathrm{~cm}$ in the control plants and also found that the average fresh weight of pods in bean were in the range of $43.1-77.4 \% \mathrm{~g}$ in case of Trichoderma treated, compared to $42.5 \mathrm{~g}$ in the control plants. Currently, the role of biological control agents is a well-established fact and has become increasingly crucial, and in several cases, complementary or even replacing the chemical counterparts where antagonistic fungi play an important role [40, 41]. In this context, Trichoderma spp. has been the cynosure of many researchers who have been contributing to biological control pursuit through use of fungi [42, 43, 44]. Furthermore, Trichoderma spp. share almost $50 \%$ of fungal Biological Control Agents market, mostly as soil/growth enhancers and this makes them interesting candidates to investigate [40].

\section{Conclusions}

Trichoderma formulation based on black gram bran proved the best among eight substrate combinations in reducing the damping off, pre-emergence - and post emergence death of seedlings and tip over. The formulation also proved to enhance growth of eggplant seedlings.

\section{REFERENCES}

[1] Haque, M.E. (2006). Study of Genetic Diversity of different Brinjal (Solanum melongena L) varieties and Lines by RAPD markers. An M.S. thesis submitted to the Dept. of Biotechnology. Bangladesh Agricultural University, Mymensingh. PP. 30-42.

[2] BBS. (2011). Year Book of Agricultural Statistics of Bangladesh. Bangladesh Bureau of Statistics, Planning Division, Ministry of Planning, Govt. of the Peoples Republic of Bangladesh, Dhaka. p.108.

[3] Klean, H. and Murugesan, K. (2003). Hyperparasitic potential Trichoderma harzianum over Fusarium sp. vasinfectum.
Indian J. Microbiol. 36(3): 145-148.

[4] Singh, R.S. (1984). Diseases of vegetable crops. Oxford \& IBH Publishing Co. New Delhi. 512p.

[5] Ahmed, H.U. and Hossain, M.M. (1985). Establishment of a disesese harberium in Bangladesh Agricultural Research Institute (BARI). Final Report, Plant Pathology Division, BARI Joydevpur, Gazipur 1701, Bangladesh.

[6] Talukder, M.J. (1974). Plant Diseases in Bangladesh. Bangladesh J. Agril. Res. 1(1):61-68.

[7] Elango, F. (1986). A simple greenhouse incubation techniques for screening true potato seedlings for their tolerance to Rhizoctonia solani induced damping off. Phytopathology. 59: 466-467.

[8] Das, A.C. (1984). Effect of cultural practices on the damping off incidence of TPS seedlings and it's chemical control in vitro. M.Sc.Ag. Thesis, Bangladesh Agricultural University. $50 \mathrm{p}$.

[9] Martin, C. and Torres, H. (1989). Comparative sessitivity of Rhizoctonia solani and Rhizoctonia like fungi to selected fungicides in vitro. . Phytopathology. 74(7): 778-781.

[10] Papavizas, G. C. (1985). Trichoderma and Gliocladium: biology, ecology, and potential for biocontrol. Annu. Rev. Phytopathol. 3: 23-54.

[11] Chet, I., and Inbar, A. (1994). Genetic diversity and vegetative compatibility among $T$. harzianum isolates. Molecular General Genetics 256: 127-135.

[12] Suseelendra, Desai and E. Schlosser. (1999). Parasitism of Sclerotium rolfsii by Trichoderma. Indian Phytopath. 52(1): 47-50.

[13] Iqbal, S.M., A. Bakhsh, S. Hussain and B.A. Malik. (1995). Microbial antagonism against Sclerotium rolfsii, the cause of collar rot of lentil. Lens Newsletter. 22 (1/2): 48-49.

[14] Tvetdyukov, A.P., Nikonov, P.V. and Yushchenko, N.P. (1994). Trichoderma.Rev. Plant Pathol. 739(4): 273.

[15] Burr, T.J., Schroth, M.M. and Suslow, T. (1978). Increased potato yields by treatment of seed pieces with specific strains of Pseudomonas flurescens and P. putida. Phytopathlogy. 68: $1378-1385$

[16] Baker, R. (1988). Trichoderma spp. As plant growth stimulants. CRC Critical Rev. Biotech. 7: 97-106.

[17] Wells, H.D., Bell, D.K. and Jaworski, C.A. (1972). Efficacy of Trichoderma harzianum as a biological control for Sclerotium rolfsii. Phytopathology. 62(4): 442-447.

[18] Backman, P.A. and Rodriguez-Kabana, R.A. (1975). A system for the growth and delivery of biological control agents to the soil. Phytopathology. 65: 819 .

[19] Akhtar, C. M. (1977). Biological control of some plant diseases lacking genetic resistance of the host crops in Pakistan. Ann. N. Y. Acad. Sci. 187: 45.

[20] Hader, Y., Chet, I. and Hanis. Y. (1979). Biological control of Rhizoctonia solani damping off with wheat bran culture of Tricoderma harzianum.Phytopathology. 69: 64-68.

[21] Mangenot, F. and Diem, H.G. (1979). Fundamental of biological control, in ecology of root pathogen Krupa, S.V. 
and Dommergues Y.R. Eds., Elsevier, Amsterdam. 107pp.

[22] Moity, T.H.A.E. and Shalta, M.N. (1981). Biological control of white rot disease Sclerotium sp. Of onion by Trichpderma harzianum, Phytopathol. Z. 100:29.

[23] Lewis, J.A. and Pavavizas, G.C. (1980). Integrated control of Rhizoctonia fruit rot of cucumber. Phytopathology. 70: 70-85.

[24] Dubey, S.C. and Patel, B. (2002). Mass multiplication of antagonist and standardization of effective dose for management of web blight of urd and mung bean. Indian Phytopatholol. 55(3):338-341.

[25] Ali, M.E. and Meah, B. (2007). Evaluation of carrier and shelf life of Trichoderma based biopesticide for increasing eggplant seed germination. Bangladesh j. crop sci. 18(2): 237-244.

[26] Ashrafuzzaman, H.A. (1976). Labortory manual of plant pathology. First edition. Department of Plant Pathology, Bangladesh Agricultural University, Mymensingh. 94 p.

[27] Babar, H.M. 1999. Studies on collar rot of sunflower. Ph.D. thesis, Dept. Plant Pathology, Bangladesh Agricultural University, Mymensingh, Bangladesh. 153 p.

[28] Dasgupta, M.K. (1988). Principles of Plant Pathology. Allied Publisher Privet Limited. New Delhi, India. 700p.

[29] Gomez KA, Gomez AA. 1984. Statistical procedure for agricultural research. Second Edition International. Rice Research Institute. John Wiley and Sons. New York. pp. $1-340$.

[30] Shamuzzaman., Islam, S.M.A. and Hossain, I. (2003a). Trichoderma culture and germination of sweet gourd seed. BangladeshJ. Seed Sci. \& Tech. 7(1\&2): 91-95.

[31] Islam, R. (2005). An integrated approach for management of phomopsis blight and fruit rot of eggplant. Ph.D. thesis, Dept. of Plant Pathology. Bangladesh Agricultural University, Mymensingh, Bangladesh.

[32] Shamuzzaman., Islam, S.M.A. and Hossain, I. (2003b). Production of Trichoderma conidia in agro-waste. Bangladesh J. Environ. Sci. 9: 146-150.

[33] Rettinassababady, C. and N. Ramadoss. (2000). Effect of different substrates on the growth and sporulation of Trichoderma viride native isolates. Agril. Sci. Digest. 20(3): 150-152.

[34] Shamarao, J., Siddaramaidah, A.L., Narayanaswamy, H. and Jahagirdar, S. (1998). Screening of substrates of mass multiplication of Trichoderma viride. Karnataka J. Agril. Sci. 11(1): 233-236.

[35] Meah, M.B., Islam, M.R. and Islam, M.M. (2004). Development of an integrated approach for management of Phomopsis Blight and Fruit rot of Eggplant in Bamgladesh. Ann. Res. Reptr. Dept. of Plant Pathology, BAU, Mymensingh, Bangladesh. p.62.

[36] Shahiduzzaman, (2009). Formulation of Compost-cum-biopesticide using Municipality waste. MS thesis, Dept. of Plant Pathology. Bangladesh Agricultural University, Mymensingh, Bangladesh. 54p.

[37] Ozbay, N., Newman, S.E. and Brown, W.M. (2004). Evalution of Trichoderma harzianum strains to control crown and root rot of greenhouse fresh market tomatoes. Horticulture and Landscape Architecture, Colorado State University, Fort Collins, Colorado, USA. Acta-Horticulturae. 635:79-85.

[38] Mukhopadhyay, A.N. (1989). National seminar and 7th Workshop of AICRP on Biological Control, Lucknow. Oct. 23-25 pp.

[39] Abd-El-Khair, H., R. Kh. M. Khalifa and Karima, H. E. Haggag. (2010). Effect of Trichoderma species on damping off diseases incidence, some plant enzymes activity and nutritional status of bean plants. Journal of American Science. 6(9):486-497.

[40] Whipps, J.M. and R.D. Lumsden. (2001). Commercial use of fungi as plant disease biological control agents: status and prospects, in: T. Butt, C. Jackson, N. Magan (Eds.), Fungal Biocontrol Agents: Progress, Problems and Potential, CABI Publishing, Wallingford. pp. 9-22.

[41] Chet, I. (1993). Biotechnology in Plant Disease Control, John Wiley and Sons, New York.

[42] Heraux, F.M.G., S.G. Hallett, K.G. Ragothama and S.C. Weller. (2005a). Composted chicken manure as a medium for the production and delivery of Trichoderma virens for weed control. Hort. Science. 40: 1394-1397.

[43] Heraux, F.M.G., S.G. Hallett, K.G. Ragothama and S.C. Weller. (2005b). Combining Trichoderma virens-inoculated compost and a rye cover crop for weed control in transplanted vegetables. Biol. Control. 34: 21-26.

[44] Ortiz, A. and S. Orduz. (2001). In vitro evaluation of Trichoderma and Gliocladium antagonism against the symbiotic fungus of the leaf-cutting ant Attacephalotes. Mycopathologia. 150: 53-60. 